\title{
Article \\ A Novel Carboxylesterase Derived from a Compost Metagenome Exhibiting High Stability and Activity towards High Salinity
}

\author{
Mingji Lu and Rolf Daniel *(1)
}

check for

updates

Citation: Lu, M.; Daniel, R. A Novel Carboxylesterase Derived from a Compost Metagenome Exhibiting High Stability and Activity towards High Salinity. Genes 2021, 12, 122. https://doi.org/10.3390/ genes12010122

Received: 21 December 2020

Accepted: 13 January 2021

Published: 19 January 2021

Publisher's Note: MDPI stays neutral with regard to jurisdictional claims in published maps and institutional affiliations.

Copyright: (c) 2021 by the authors. Licensee MDPI, Basel, Switzerland. This article is an open access article distributed under the terms and conditions of the Creative Commons Attribution (CC BY) license (https:/ / creativecommons.org/licenses/by/ $4.0 /)$.
Department of Genomic and Applied Microbiology and Göttingen Genomics Laboratory, Institute of Microbiology and Genetics, Georg-August-University of Göttingen, Grisebachstr. 8, 37077 Göttingen, Germany; mingji.lu@biologie.uni-goettingen.de

* Correspondence: rdaniel@gwdg.de; Tel.: +49-551-393-3827

Abstract: Halotolerant lipolytic enzymes have gained growing interest, due to potential applications under harsh conditions, such as hypersalinity and presence of organic solvents. In this study, a lipolytic gene, est56, encoding 287 amino acids was identified by functional screening of a compost metagenome. Subsequently, the gene was heterologously expressed, and the recombinant protein (Est56) was purified and characterized. Est56 is a mesophilic $\left(\mathrm{T}_{\mathrm{opt}} 50^{\circ} \mathrm{C}\right)$ and moderate alkaliphilic $\left(\mathrm{pH}_{\text {opt }} 8\right)$ enzyme, showing high thermostability at 30 and $40{ }^{\circ} \mathrm{C}$. Strikingly, Est56 is halotolerant as it exhibited high activity and stability in the presence of up to $4 \mathrm{M} \mathrm{NaCl}$ or $\mathrm{KCl}$. Est56 also displayed enhanced stability against high temperatures $\left(50\right.$ and $\left.60^{\circ} \mathrm{C}\right)$ and urea $(2,4$, and $6 \mathrm{M})$ in the presence of $\mathrm{NaCl}$. In addition, the recently reported halotolerant lipolytic enzymes were summarized. Phylogenetic analysis grouped these enzymes into 13 lipolytic protein families. The majority (45\%) including Est56 belonged to family IV. To explore the haloadaptation of halotolerant enzymes, the amino acid composition between halotolerant and halophilic enzymes was statistically compared. The most distinctive feature of halophilic from non-halophilic enzymes are the higher content of acidic residues (Asp and Glu), and a lower content of lysine, aliphatic hydrophobic (Leu, Met and Ile) and polar (Asn) residues. The amino acid composition and 3-D structure analysis suggested that the high content of acidic residues (Asp and Glu, 12.2\%) and low content of lysine residues (0.7\%), as well as the excess of surface-exposed acidic residues might be responsible for the haloadaptation of Est56.

Keywords: carboxylesterases; metagenome; compost; lipolytic enzymes; halotolerance; halophilic; haloadaptation

\section{Introduction}

Halophilic and halotolerant enzymes, which show resistance to salinity, are one of the major groups of extremozymes with industrial relevance. Microorganisms growing optimally at high salt concentrations are reservoirs for halophilic and halotolerant enzymes. They are generally divided into halophiles and halotolerant organisms [1,2]. To survive in high salinity, osmotic balance between cell cytoplasm and the external medium has to be maintained [3]. Halophilic archaea of the Halobacteriales order primarily adopt the "salt-in" strategy by accumulating equimolar concentrations of inorganic ions such as potassium and chloride ions $[4,5]$. This mechanism of osmoregulation results in intracellular enzymes, which evolve to halophilic types [6,7], which intrinsically show high activity and stability towards increasing salinity. In contrast, halophilic methanogenic archaea, as well as most halophilic and halotolerant bacteria largely employ the "salt-out" strategy by excluding salt from the cell inside and synthesizing and/or accumulating compatible organic osmolytes [8]. Some show also a combination of "salt-in" and "salt-out" strategies $[9,10]$. Halotolerant enzymes identified from "salt-out" microorganisms usually show 
different levels of salinity resistance [11-13]. Unlike most halophilic enzymes, which are inactive under low salt concentrations, halotolerant enzymes are still active in the absence of $\mathrm{NaCl}$ [14].

Haloadaptation of halophilic enzymes has been extensively studied by amino acid sequence and 3D structure comparison [15-17]. The presence of an unusually high proportion of acid residues and a drastic reduction of lysine residues on the surface of proteins play a key role in haloadaptation of enzymes [18,19]. Comparative analyses of halotolerant and halophilic enzymes with respect to amino acid compositions or 3D structures are rare. Given that scrutiny of protein and genome sequences may not unravel small differences during sequence-based comparative analysis [2,20], homologous enzymes sharing relatively high sequence similarity and conserved 3D structure would be promising in unveiling differences potentially related to shared strategies of adaptation to high salt environments.

Lipolytic enzymes, including esterases (EC 3.1.1.1, carboxylesterase) and true lipases (EC 3.1.1.3, triacylglycerol acyl hydrolase), are involved in catalyzing the cleavage and formation of ester bonds. Esterases prefer short-chain substrates with an acyl chain length of less than 10 carbon atoms, while lipases mainly catalyze the hydrolysis of long-chain triacylglycerols ( $\geq 10$ carbon atoms) [21]. A distinguishing feature of lipolytic enzyme sequences is the conserved catalytic triad composed of a serine residue, which is located in the GXSXG consensus sequence, an aspartate or glutamate, and a histidine residue [22]. Most lipolytic enzymes also exhibit a similar core topology that typically consists of parallel $\beta$-pleated strands connected by $\alpha$-helices [21]. Based on amino acid sequences and biological properties of lipolytic enzymes, 19 families (family I-XIX) have been identified [23]. Subsequently, new families such as EstLiu [24], Em3L4 [25], FLS18 [26], and Est9x [27] were added. Halophilic and halotolerant lipolytic enzymes have been detected in different families but the majority belonged to family IV [11,28-30]. Family IV esterases share high amino acid sequence similarity with mammalian hormone-sensitive lipases (HSL) and hence have also been referred to as the HSL family [21]. Previous studies on members of this family have predominantly explored the thermostability [31-33] and substrate specificity [34,35]. However, studies on salt tolerance of HSL family members are often missing.

Halophilic lipolytic enzymes are rare, among them, only LipC [36], MGS-B1 [37], and LipS2 [38] were characterized. In contrast, an increasing number of halotolerant lipolytic enzymes have been identified, through culture-dependent [28,39] and metagenomic approaches [29,40-42]. Apart from general features, such as broad substrate spectrum, chemo-, regio-, and enantio-selectivity and nonrequirement of cofactors, halophilic and halotolerant enzymes also tend to be resistant to organic solvents [15,31,43]. High salinity or presence of organic solvents both result in reduced water activity. Thus, halophilic and halotolerant lipolytic enzymes are advantageous in applications involving nonaqueous and aqueous/organic media, such as the degradation of organic pollutants in saline wastewater, bioremediation of oil spills, production of inter-esterification substances in food industry and nonaqueous synthesis of non-natural chemical compounds [14,44,45].

Composting is a process of decomposition and humification of organic matter [46]. During composting, enzymes secreted by microorganisms play key roles in degrading various organic substances. Recently, extremophilic enzymes, such as thermophilic, organic solvent tolerant, and alkaliphilic lipolytic enzymes, have been successfully identified from compost metagenomes [47-49]. However, there are no current reports of halophilic or halotolerant lipolytic enzymes from compost. In our previous study, a compost sample at the thermophilic stage $\left(55^{\circ} \mathrm{C}\right)$ was used to construct a metagenomic plasmid library [50] of which the identified esterase-encoding gene est56 was selected for characterization. Est56 was a novel member of lipolytic family IV and further characterized as halotolerant. The haloadaptation mechanism of Est56 was also explored by comparing its amino acid composition with other halotolerant and halophilic enzymes, and subsequent analysis of homology-modelled 3D structures. 


\section{Materials and Methods}

\subsection{Bacterial Strains and Plasmids}

The lipolytic recombinant plasmid (pFLD56) harboring the putative lipolytic gene est56 was derived from the functional screen of the metagenomic compost library as described in our previous study [50]. The plasmid pFLD56 was used as template for amplification of est56. E. coli strain BL21(DE3) and the plasmid pET101/D-TOPO ${ }^{\circledR}$ (Invitrogen, Karlsruhe, Germany) were used as expression host and vector, respectively.

\subsection{Identification and Analysis of Est56 Sequence}

Putative open reading frames (ORF) encoding lipolytic enzymes were initially predicted using the ORF Finder program (http:/ /www.ncbi.nlm.nih.gov/gorf/gorf.html), and further verified using FramePlot analysis [51]. Potential signal peptides were detected using SignalP 4.0 [52]. Amino acid sequence similarity searches were performed using the BLASTP program against the public GenBank database [53]. Amino acid sequences of esterases homologous to the deduced gene product of est5 6 were aligned by employing clustalW. Secondary structure prediction was performed with I-TASSER [54]. Annotation of aligned sequences was performed with ESPript 3.0 [55].

\subsection{Cloning and Expression of Est56}

The putative lipolytic gene est56 was amplified using the following primers: $5^{\prime}-$ CACCATGCTCGCGCAGTCAC- ${ }^{\prime}$ and 5 $^{\prime}$-CCCCTGGCGCGGGTAGTGTTCG- ${ }^{\prime}$. The est56 PCR product was cloned into pET101/D-TOPO ${ }^{\circledR}$ vector (Invitrogen, Germany), following the manufacturer's instructions. The resulting recombinant plasmid was transformed into E. coli BL21 (DE3) cells. For expression of est56, a $6 \mathrm{~mL}$ preculture, incubated overnight, was used to inoculate $600 \mathrm{~mL}$ LB medium containing $100 \mu \mathrm{g} / \mathrm{mL}$ ampicillin. The culture was incubated overnight with shaking at $30^{\circ} \mathrm{C}$ to an $\mathrm{OD}_{600}$ of 0.6. Expression was induced by adding IPTG (isopropyl-b-D thiogalactopyranoside) to a final concentration of $0.5 \mathrm{mM}$. After incubation for $6 \mathrm{~h}$ at $30^{\circ} \mathrm{C}$, cells were harvested by centrifugation $(7000 \times g, 10 \mathrm{~min}$, $\left.4{ }^{\circ} \mathrm{C}\right)$, suspended in lysis-equilibration-wash buffer $\left(50 \mathrm{mM} \mathrm{NaH}_{2} \mathrm{PO}_{4}, 300 \mathrm{mM} \mathrm{NaCl}, \mathrm{pH}\right.$ 8), and then lysed on ice by sonication using a UPS200S homogenizer (Hielscher Ultrasonics $\mathrm{GmbH}$, Teltow, Germany).

\subsection{Purification of Recombinant Est56}

To purify His $_{6}$-tagged Est56, Protino ${ }^{\circledR}$ Ni-TED 2000 packed columns (Macherey-Nagel, Düren, Germany) were used as recommended by the manufacturer. SDS-PAGE was performed to determine the purity and molecular mass of Est56. Protein concentration was measured by the Bradford method [56]. Finally, fractions containing the purified enzyme were pooled and dialyzed against $50 \mathrm{mM}$ sodium phosphate buffer $(\mathrm{pH} 8)$ at $4{ }^{\circ} \mathrm{C}$.

\subsection{Esterase Standard Assay}

Unless otherwise mentioned, Est56 activity was measured in $1.0 \mathrm{~mL}$ assay buffer containing $50 \mathrm{mM}$ sodium phosphate $(\mathrm{pH} 8)$ and $1 \mathrm{mM} p$-nitrophenyl ( $p$-NP) butyrate (Sigma-Aldrich, Munich, Germany), at $50{ }^{\circ} \mathrm{C}$. The amount of $p$-NP released by enzymecatalyzed hydrolysis was continuously monitored for at least $2 \mathrm{~min}$ at a wavelength of $410 \mathrm{~nm}$ against an enzyme-free reference. One unit of enzymatic activity was defined as the amount of Est56 needed to release $1 \mu \mathrm{mol}$ of $p$-NP per minute under the assay conditions. All experiments were performed in at least triplicate, and extinction coefficients of $p$-NP under every assay condition were determined. Results are shown as mean values \pm standard deviation (SD). 


\subsection{Characterization of Est56}

\subsubsection{Substrate Specificity}

Substrate specificity of Est56 was assessed under standard assay conditions using $1 \mathrm{mM} p$-NP esters (Sigma-Aldrich, Munich, Germany) of different chain lengths as substrates: $p$-NP acetate (C2), $p$-NP butyrate (C4), $p$-NP valerate (C5), $p$-NP caproate (C6), $p$-NP caprylate (C8), $p$-NP caprate (C10), $p$-NP laurate (C12), $p$-NP myristate (C14), and $p$ $\mathrm{NP}$ palmitate (C16). All substrates were prepared as a $0.1 \mathrm{M}$ stock solution dissolved in isopropanol. For long chain substrates $(>\mathrm{C} 10)$, the stock solution was first heated $\left(50^{\circ} \mathrm{C}\right)$ for a short time until the formation of clear transparent solution [40]. Initial reaction rates were calculated by estimating Est56 activity with different substrate concentrations ranging from 5 to $5000 \mu \mathrm{M}$. Michaelis-Menten constant $\left(\mathrm{K}_{\mathrm{m}}\right)$ and the maximal velocity $\left(\mathrm{V}_{\max }\right)$ were determined by employing Lineweaver-Burk plots [57].

\subsubsection{Effect of Temperature and $\mathrm{pH}$}

Optimum temperature of Est56 activity was determined between 20 and $70{ }^{\circ} \mathrm{C}$. To assess protein thermostability, Est56 was preincubated in assay buffer at 30, 40, 50, and $60^{\circ} \mathrm{C}$ for different time periods, and subsequently, residual activity was measured under standard assay condition.

Due to $\mathrm{pH}$-dependent absorption of $\mathrm{p}-\mathrm{NP}$ in acidic buffers [58], the effect of $\mathrm{pH}$ on Est56 activity was determined between $\mathrm{pH}$ values 3 and 10 at $348 \mathrm{~nm}$ (the $\mathrm{pH}$-independent isosbestic wavelength). The overlapping buffer systems used comprised $50 \mathrm{mM}$ acetate buffer ( $\mathrm{pH} 3.0$ to 6.0$), 50 \mathrm{mM}$ sodium phosphate buffer ( $\mathrm{pH} 6.0$ to 8.0$), 50 \mathrm{mM}$ TAPS (3-(2,4 dinitrostyrl)-(6R,7R-7-(2-thienylacetamido)-ceph-3-em-4-carboxylic acid) buffer ( $\mathrm{pH} 8.0$ 9.0), and $50 \mathrm{mM}$ CHES (N-cyclohexyl-2-aminoethanesulfonic acid) buffer (pH 9.0 to 10.0). The effect of $\mathrm{pH}$ on Est56 stability was examined by preincubating the enzyme at the respective $\mathrm{pH}$ value at $10^{\circ} \mathrm{C}$ for $24 \mathrm{~h}$. Subsequently, residual activity was measured under standard assay condition.

\subsubsection{Effect of Salinity}

The effect of salinity on Est56 activity was measured by adding 0.5 to $4 \mathrm{M} \mathrm{NaCl}$ or $\mathrm{KCl}$ to the standard reaction assay mixture. Est56 stability against salt was determined by incubating the enzyme in assay buffer containing $\mathrm{NaCl}(0.5$ to $4 \mathrm{M})$ at $10{ }^{\circ} \mathrm{C}$ for $24 \mathrm{~h}$. Residual activity was measured under standard assay conditions.

Salt has been reported to protect halophilic proteins against denaturants (such as high temperature and urea) [18]. In this study, the protective effect of $\mathrm{NaCl}$ was investigated by adding different amounts of $\mathrm{NaCl}(0-4 \mathrm{M})$ to the incubation buffer, in which Est56 was incubated at different temperatures or in the presence of different amounts of urea. Specifically, Est56 was incubated at high temperatures $\left(50\right.$ or $\left.60^{\circ} \mathrm{C}\right)$ for $30 \mathrm{~min}$. For urea impact, Est56 was incubated with different amounts of urea $(2,4$, and $6 \mathrm{M})$ at $10^{\circ} \mathrm{C}$ for $24 \mathrm{~h}$. Each additive was equalized to the same final concentration in the assay buffer, and the residual activity was measured under standard assay conditions. A blank reference was prepared using the buffer solution without enzyme but containing the same amount and type of additive. Activity measured before incubation was taken as $100 \%$.

\subsubsection{Effect of Organic Solvents}

The effect of organic solvents on Est56 stability was assayed by incubating Est56 in the presence of $15 \%$ and $30 \%(v / v)$ water-miscible organic solvents (DMSO, methanol, ethanol, acetone, isopropanol, and 1-propanol) or water-immiscible organic solvents (ethyl acetate, diethyl ether, chloroform, and toluene) at $10{ }^{\circ} \mathrm{C}$ for $24 \mathrm{~h}$ under constant shaking. Residual activity was measured under standard assay conditions.

\subsubsection{Effect of Other Additives}

The effect of metal ions including $\mathrm{K}^{+}, \mathrm{Ca}^{2+}, \mathrm{Mn}^{2+}, \mathrm{Mg}^{2+}, \mathrm{Zn}^{2+}, \mathrm{Fe}^{2+}, \mathrm{Cu}^{2+}, \mathrm{Ni}^{2+}, \mathrm{Fe}^{3+}$, and $\mathrm{Al}^{3+}$ and inhibitors including phenylmethyl-sulfonyl fluoride (PMSF), dithiothreitol 
(DTT), and ethylenediaminetetraacetic acid (EDTA) was measured at concentrations of 1 and $10 \mathrm{mM}$. In addition, the impact of detergents such as Triton X-100, Tween 20, Tween 80, and SDS at concentrations of $0.1 \%, 1 \%$ and $5 \%(v / v)$ on enzyme activity was investigated. The catalytic activity of Est56 was measured under standard reaction conditions by directly adding each additive to the standard assay mixture. Activity measured in additive-free assay buffer was regarded as 100\% activity, while reactions that included corresponding additive but no enzyme were used as blanks.

\subsection{Sequence Analysis of Halotolerant Enzymes}

Phylogenetic trees were constructed with the neighbor-joining method using MEGA version 7 [59]. For this purpose, Est56, other reported halotolerant, and reference lipolytic enzyme sequences retrieved from GenBank were employed (Table S1). A bootstrap value of 500 replicates was used to estimate the confidence level [60]. The phylogenetic tree was subsequently visualized by GraPhlAn [61]. In addition, a tree containing only family IV esterases was constructed.

Characterized halophilic lipolytic enzymes are rare but enzymes from halophilic microorganism that adopt the "salt-in" strategy were evolved to be halophilic [6]. Thus, we retrieved 22 putative halophilic lipolytic enzymes originating from archaea of the Halobacteriales order from GenBank (Table S2). The halophilic feature of each archaeal strain was checked on HaloDom webserver (http: / / www.halodom.bio.auth.gr) [62]. We summarized experimentally confirmed halophilic proteins as controls (Table S3). Thereafter, we used HT_Lip, HP_Lip, and HP_Enz to refer to the 40 halotolerant lipolytic enzymes, 22 putative halophilic lipolytic enzymes, and 16 experimentally confirmed halophilic proteins, respectively. Amino acid composition, theoretical pI values, and molecular weight of each protein were calculated by the ProtParam tool at Expasy (www.expasy.org) [63].

Differences in amino acid compositions among HT_Lip, HP_Lip, and HP_Enz were statistically compared. Individual amino acids were analyzed as variants for each enzyme. Nonparametric Kruskal-Wallis (KW) and Mann-Whitney (MW) pairwise post hoc tests were used to evaluate median differences among univariate groups. Analysis of similarities (ANOSIM) test was used to pairwise compare the overall differences between multivariate groups based on Bray-Curtis distance, with 9999 permutations. A high $\mathrm{R}$ value generated by the ANOSIM test indicates a high dissimilarity between groups. Similarity percentage (SIMPER) tool calculates the average contribution of individual amino acids to the average dissimilarity between groups based on Bray-Curtis similarity. Statistical analyses were performed with R (http:/ / www.r-project.org) using the "vegan" package [64].

\subsection{Homology Modeling and Putative Structure Analysis}

Based on deduced amino acid sequence, the tertiary structure prediction of Est56 was performed by I-TASSER [54]. PyMOL (PyMOL molecular graphics system, DeLano Scientific, Palo Alto, CA, USA; http:/ / www.pymol.org) was used to visualize the predicted model. The analog with the highest TM score was also selected for structural superimposition. The surface electrostatic potential was calculated by the APBS plugin [65] and visualized by PyMOL.

\subsection{Accession Numbers}

The amino acid sequence of Est56 is available in the GenBank database under accession number KR149569.1. The compost metagenome sequences are available in the NCBI sequence read archive (SRA) under the accession number SRR13115019.

\section{Results}

\subsection{Identification and Sequence Analysis of a Novel Lipolytic Gene}

A metagenomic plasmid library derived from compost using Escherichia coli as host was constructed and function-based screened for genes conferring lipolytic activity as previously described [50]. An E. coli clone showing strong lipolytic activity (large halos) 
on indicator plates was selected for further characterization. Sequence analysis of the plasmid insert (6.1 kb, Figure S1) revealed a putative lipolytic gene (est56, $864 \mathrm{bp}$ ) encoding 287 amino acids. Putative signal peptides indicating extracytoplasmic localization were not detected in the deduced protein sequence. Similarity searches showed that protein sequences similar to Est56 were mainly identified during metagenome screenings. These comprised ELP45 isolated from a forest topsoil [66], EstC23 from mountain soil [67], Est06 from forest soil [68], and EstMY from activated sludge [69], which showed $62 \%, 61 \%, 60 \%$, and $60 \%$ amino acid identity to Est56, respectively.

Multiple sequence alignments of Est56 with other esterases revealed that Est56 belongs to the HSL group (family IV) of lipolytic proteins. The conserved family IV motif H-G-G was present in the Est56 protein at amino acid sequence positions from 62 to 64 . This motif plays an essential role in the stabilization of the oxyanion hole and catalysis. The catalytic triad composed of $\mathrm{Ser}^{132}$, Glu ${ }^{226}$, and $\mathrm{His}^{256}$, as well as another conserved motif E-X-L-XD-D (amino acid residues from 226 to 231), was also detected in Est56 amino acid sequence (Figure S2).

\subsection{Purification of Recombinant Est56 and Substrate Specificity}

Est56 was heterologously produced in E. coli BL21 (DE3). After purification by Ni-TED affinity chromatography, Est56 was purified 73-fold with a specific activity of $90.44 \mathrm{U} / \mathrm{mg}$ (Table S4). SDS-PAGE revealed a single band with a molecular mass of approximately $34.0 \mathrm{kDa}$ (Figure S3). This is consistent with the calculated protein mass including the sequences for the $\mathrm{V} 5$ epitope and $\mathrm{His}_{6}$-tag, which were added during cloning of est56.

Assays with $p$-NP esters showed that Est56 exhibited a substrate preference for esters with short-chain fatty acids such as $p$-NP acetate (C2), $p$-NP butyrate (C4), $p$-NP valerate (C5), and $p$-NP caproate (C6). The enzyme did show little or no significant activity by employing $p$-NP esters with long-chain fatty acids (C8-C16) as substrates (Figure S4). This indicates that Est56 is an esterase and not a lipase [21]. The maximal specific activity was detected with $p$-NP butyrate (C4). The $\mathrm{K}_{\mathrm{m}}$ and $\mathrm{V}_{\max }$ values with this substrate were $128.0 \mu \mathrm{M}$ and $102.0 \mathrm{U} / \mathrm{mg}$, respectively.

\subsection{Effect of Temperature and $p H$}

Est56 retained high activity (above $40 \%$ ) over the entire tested temperature range from 20 to $70{ }^{\circ} \mathrm{C}$ with maximal activity at $50{ }^{\circ} \mathrm{C}$ (Figure 1a). Despite the high activity (above $80 \%$ ) of Est56 at 50 and $60^{\circ} \mathrm{C}$, thermostability at 50 and $60^{\circ} \mathrm{C}$ was low. Est56 retained $50 \%$ activity after $30 \mathrm{~min}$ of incubation at $50{ }^{\circ} \mathrm{C}$ and $12.4 \%$ after $10 \mathrm{~min}$ at $60^{\circ} \mathrm{C}$. However, Est56 showed high stability for extended incubation times at 30 and $40^{\circ} \mathrm{C}$, with a half-life of 192 and $16 \mathrm{~h}$, respectively (Figure $1 \mathrm{c}$ ).

Est56 exhibited more than $80 \%$ activity between $\mathrm{pH} 6$ and 8, with maximal activity at pH 8 (Figure 1b). Similarly, Est56 was most stable from pH 6 to 8, retaining more than $90 \%$ residual activity after $24 \mathrm{~h}$ incubation at $10{ }^{\circ} \mathrm{C}$ (Figure 1d).

\subsection{Effect of Salinity}

Addition of salt $(\mathrm{NaCl}$ or $\mathrm{KCl})$ produced a stimulatory effect on Est56 activity, with an enhanced activity at $\mathrm{NaCl}$ and $\mathrm{KCl}$ concentrations of up to $2.5 \mathrm{M}$. Maximal activities compared to the reference without addition were recorded in the presence of $1.5 \mathrm{M} \mathrm{NaCl}$ (130.4\%) and $1 \mathrm{M} \mathrm{KCl}(141.6 \%)$. At higher concentrations, Est56 activity decreased gradually with increasing concentration of $\mathrm{NaCl}$ and $\mathrm{KCl}$. Notably, Est56 still retained approximately $90 \%$ activity at $3 \mathrm{M} \mathrm{NaCl}$ and $3.5 \mathrm{M} \mathrm{KCl}$ and $40 \%$ activity at $4 \mathrm{M} \mathrm{NaCl}$ and $\mathrm{KCl}$ (Figure 2a).

As for the stability, Est56 was stable over the tested $\mathrm{NaCl}$ and $\mathrm{KCl}$ concentration ranges $(0-4 \mathrm{M})$, with almost unaltered activity after $24 \mathrm{~h}$ incubation at $10^{\circ} \mathrm{C}$ (Figure $2 \mathrm{~b}$ ). 

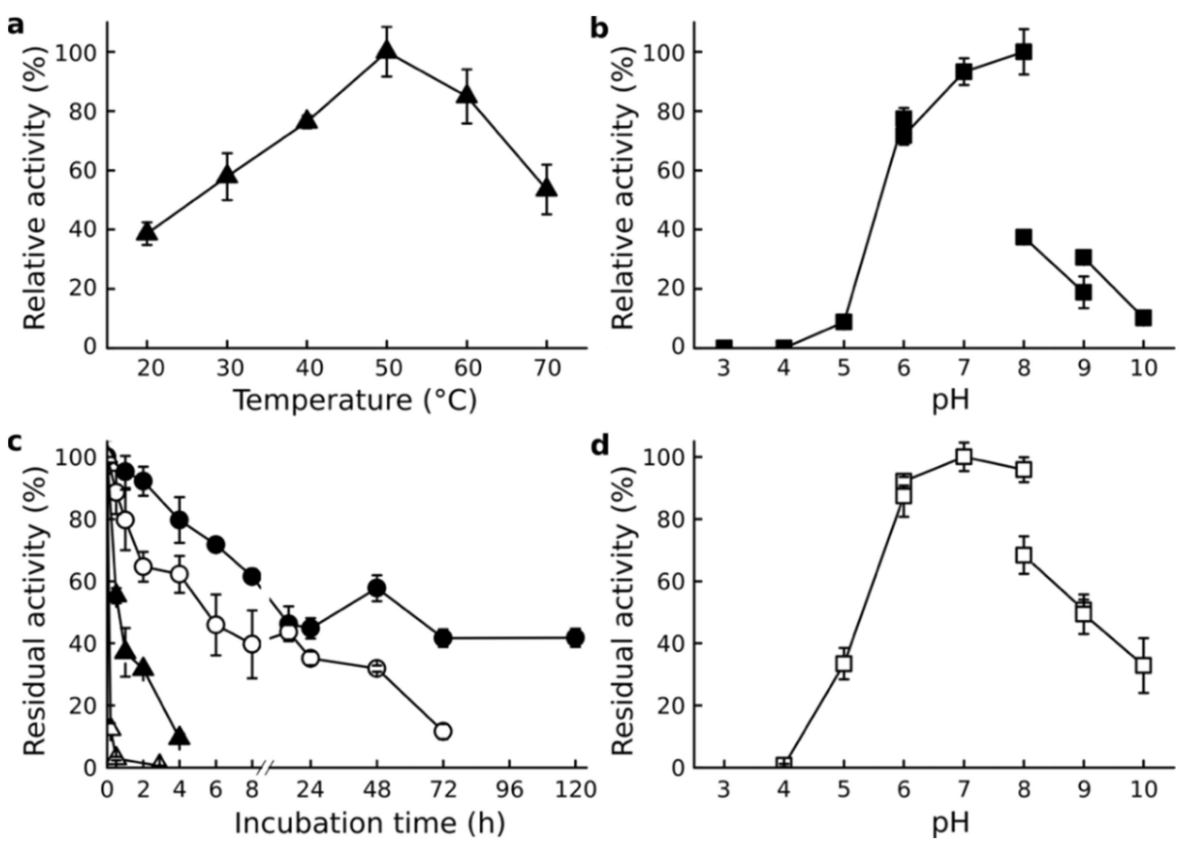

Figure 1. Effect of temperature and $\mathrm{pH}$ on Est56 activity. (a) Effect of temperature on Est56 activity; the maximal activity $\left(153.9 \mathrm{U} / \mathrm{mg}\right.$ ) at $50{ }^{\circ} \mathrm{C}$ was taken as $100 \%$. (b) Effect of pH on Est56 activity; the maximal activity $(90.4 \mathrm{U} / \mathrm{mg})$ at $\mathrm{pH} 8$ was taken as $100 \%$. (c) Thermostability of Est56 at $30{ }^{\circ} \mathrm{C}$ (closed circle), $40{ }^{\circ} \mathrm{C}$ (open circle), $50{ }^{\circ} \mathrm{C}$ (closed triangle), and $60^{\circ} \mathrm{C}$ (open triangle); specific activity $(87.2 \mathrm{U} / \mathrm{mg})$ measured at the start of the incubation and under standard assay conditions was taken as $100 \%$. (d) Effect of $\mathrm{pH}$ on Est56 stability was measured by incubating Est56 at $4{ }^{\circ} \mathrm{C}$ for $24 \mathrm{~h}$, the maximal residual activity $(33.1 \mathrm{U} / \mathrm{mg})$ at $\mathrm{pH} 7$ was taken as $100 \%$.
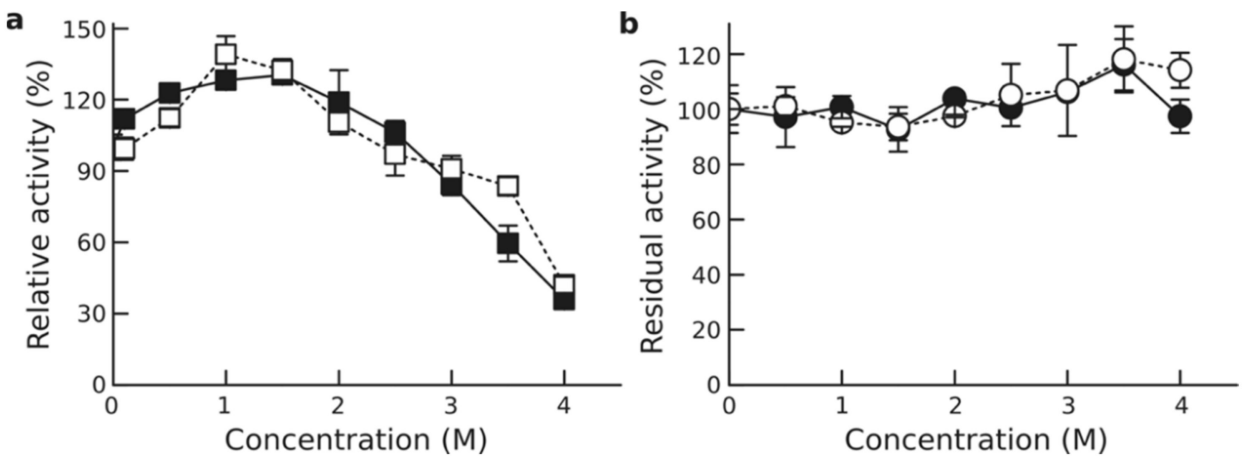

Figure 2. Effect of salinity on Est56 activity and stability. (a) Effect of $\mathrm{NaCl}$ (closed square) and $\mathrm{KCl}$ (open square) on Est56 activity. (b) Effect of $\mathrm{NaCl}$ (closed circle) and $\mathrm{KCl}$ (open circle) on Est56 stability. Specific activities corresponding to $100 \%$ activity were 93.1 and $94.1 \mathrm{U} / \mathrm{mg}$ for graph (a) and $(\mathbf{b})$, respectively.

\subsection{Protective Effect of $\mathrm{NaCl}$ against Denaturants}

The presence of $\mathrm{NaCl}$ enhanced stability of Est56 to temperature (Table 1). At $50{ }^{\circ} \mathrm{C}$, the addition of 1,2 , and $3 \mathrm{M} \mathrm{NaCl}$ significantly $(p<0.05)$ increased Est56 residual activity (above 70\%) compared to that incubated in the salt-free assay. The best stabilization effect was detected at $2 \mathrm{M} \mathrm{NaCl}$. However, incubation with $4 \mathrm{M} \mathrm{NaCl}$ significantly $(p<0.05)$ decreased Est56 stability. At $60^{\circ} \mathrm{C}$, Est56 was almost inactivated after 30 -min without $\mathrm{NaCl}$ addition, whereas a significant increase in residual activity was detected by adding 1, 2, 3, or $4 \mathrm{M} \mathrm{NaCl}$. 
Table 1. Role of $\mathrm{NaCl}$ in protecting Est56 against denaturants.

\begin{tabular}{|c|c|c|c|c|c|}
\hline & \multicolumn{5}{|c|}{ Residual Relative Activity (\%) ${ }^{a}$} \\
\hline & $\mathbf{0} \mathbf{M}$ & $1 \mathrm{M}$ & $2 \mathrm{M}$ & $3 \mathbf{M}$ & $4 \mathrm{M}$ \\
\hline \multicolumn{6}{|c|}{ Temperature ${ }^{b}$} \\
\hline $50^{\circ} \mathrm{C}$ & $54.9 \pm 2.4$ & $71.3 \pm 8.1 *$ & $82.8 \pm 7.4^{* *}$ & $72.9 \pm 4.2 *$ & $38.9 \pm 3.1$ ** \\
\hline $60{ }^{\circ} \mathrm{C}$ & $1.4 \pm 0.7$ & $12.7 \pm 2.2^{* *}$ & $11.8 \pm 1.6^{* *}$ & $8.0 \pm 0.7^{* *}$ & $10.6 \pm 0.6^{* *}$ \\
\hline \multicolumn{6}{|l|}{ Urea $^{c}$} \\
\hline $2 \mathrm{M}$ & $36.3 \pm 4.7$ & $36.2 \pm 4.0$ & $43.0 \pm 4.7$ & $54.0 \pm 2.4^{* *}$ & $41.5 \pm 9.5$ \\
\hline $4 \mathrm{M}$ & $19.5 \pm 3.5$ & $31.6 \pm 2.5^{* *}$ & $33.6 \pm 2.2^{* *}$ & $29.3 \pm 4.0 *$ & $\mathrm{ND}^{\mathrm{d}}$ \\
\hline $6 \mathrm{M}$ & $17.2 \pm 2.4$ & $28.6 \pm 2.2^{* *}$ & $\mathrm{ND}^{\mathrm{d}}$ & $\mathrm{ND}^{\mathrm{d}}$ & $\mathrm{ND}^{\mathrm{d}}$ \\
\hline
\end{tabular}

\footnotetext{
${ }^{a}$ Residual activity was measured after incubation with different amounts of $\mathrm{NaCl}$. Two-sample $t$ test was performed between residual activities incubated with and without $\mathrm{NaCl}$. ${ }^{*} \alpha=0.05$; ${ }^{* *} \alpha=0.01$.

${ }^{b}$ Est56 was incubated at 50 or $60^{\circ} \mathrm{C}$ for $30 \mathrm{~min}$ in the presence of different concentrations of $\mathrm{NaCl}$. Specific activity $(41.9 \mathrm{U} / \mathrm{mg})$ measured before incubation was taken as $100 \% .{ }^{\mathrm{c}}$ Est56 was incubated at $10^{\circ} \mathrm{C}$ for $24 \mathrm{~h}$ in the presence of different combinations of $\mathrm{NaCl}$ and urea. Specific activity $(45.8 \mathrm{U} / \mathrm{mg})$ measured before incubation was taken as $100 \%{ }^{\mathrm{d}}$ Not detectable.
}

Urea is another denaturant that can cause inactivation of an enzyme directly and indirectly [70]. Addition of $3 \mathrm{M} \mathrm{NaCl}$ significantly $(p<0.05)$ enhanced Est56 tolerance against $2 \mathrm{M}$ urea, with the residual activity increasing from $36.3 \%$ without $\mathrm{NaCl}$ addition to $54.0 \%$ in the presence of $3 \mathrm{M} \mathrm{NaCl}$. A stabilizing effect of $\mathrm{NaCl}(p<0.05)$ on Est56 activity was also observed in the presence of 4 or $6 \mathrm{M}$ urea (Table 1).

\subsection{Effect of Organic Solvents}

Generally, Est56 exhibited enhanced activity after incubating with $15 \%$ and $30 \%(v / v)$ water-miscible organic solvents (Table 2), with the exception of $30 \%(v / v)$ 1-propanol, which caused a considerable loss of Est56 residual activity (23.0\%). The highest stimulation of residual activity $(286 \%)$ was observed after incubation with $30 \%(v / v)$ isopropanol. In the presence of water-immiscible organic solvents, Est 56 was inhibited by $15 \%$ and $30 \%$ $(v / v)$ ethyl acetate, chloroform, and toluene (Table 3). Est56 retained its full activity after incubation with $15 \%$ and $30 \%(v / v)$ diethyl ether.

Table 2. Effect of water-miscible organic solvents on Est56 stability.

\begin{tabular}{ccc}
\hline \multirow{2}{*}{ Organic Solvent } & \multicolumn{2}{c}{ Residual Activity (\%) ${ }^{\mathbf{a}}$} \\
\cline { 2 - 3 } & $\mathbf{1 5 \%} \mathbf{( v / v )}$ & $\mathbf{3 0 \%}(\boldsymbol{v} / \boldsymbol{v})$ \\
\hline DMSO & $135.0 \pm 11.8$ & $135.4 \pm 4.7$ \\
Methanol & $116.1 \pm 6.7$ & $96.6 \pm 7.6$ \\
Ethanol & $116.2 \pm 8.7$ & $107.3 \pm 4.2$ \\
Acetone & $138.3 \pm 8.9$ & $115.3 \pm 14.8$ \\
Isopropanol & $136.3 \pm 10.1$ & $286.6 \pm 9.0$ \\
1-Propanol & $114.0 \pm 3.7$ & $23.0 \pm 1.0$ \\
\hline
\end{tabular}

\footnotetext{
${ }^{a}$ Specific activity $(33.4 \mathrm{U} / \mathrm{mg})$ incubated in the organic solvent-free assay buffer was taken as $100 \%$.
}

Table 3. Effect of water-immiscible organic solvents on Est56 stability.

\begin{tabular}{ccc}
\hline \multirow{2}{*}{ Organic Solvent } & \multicolumn{2}{c}{ Residual Activity (\%) ${ }^{\mathbf{a}}$} \\
\cline { 2 - 3 } & $\mathbf{1 5 \% ( \boldsymbol { v } / \boldsymbol { v } )}$ & $\mathbf{3 0 \%}(\boldsymbol{v} / \boldsymbol{v})$ \\
\hline Ethyl acetate & $55.3 \pm 8.1$ & $50.2 \pm 3.5$ \\
Diethyl ether & $110.8 \pm 5.7$ & $106.7 \pm 10.8$ \\
Chloroform & $46.5 \pm 0.5$ & $6.3 \pm 2.5$ \\
Toluene & $50.0 \pm 2.2$ & $54.9 \pm 0.7$ \\
\hline
\end{tabular}

\footnotetext{
${ }^{a}$ Specific activity $(53.4 \mathrm{U} / \mathrm{mg}$ ) incubated in the organic solvent-free assay buffer was taken as $100 \%$.
} 


\subsection{Effect of Other Additives}

Metal ions exhibited different effects on Est56 activity (Table S5). The addition of $\mathrm{Al}^{3+}$ and $\mathrm{Ca}^{2+}$ at 1 and $10 \mathrm{mM}$ had a stimulatory effect (approximately 130\%). Est56 retained its full activity in the presence of 1 and $10 \mathrm{mM} \mathrm{Mg}^{2+}$. In contrast, Est56 activity slightly decreased to approximately $80 \%$ in the presence of $1 \mathrm{mM} \mathrm{Fe}^{2+}, 10 \mathrm{mM} \mathrm{Mn}^{2+}$, and 1 and $10 \mathrm{mM} \mathrm{Zn}^{2+}$. The additives $\mathrm{Cu}^{2+}$ and $\mathrm{Ni}^{2+}$ at 1 and $10 \mathrm{mM}$ and $\mathrm{Fe}^{2+}$ and $\mathrm{Fe}^{3+}$ at $10 \mathrm{mM}$ were deleterious to Est56, as enzyme activity dropped to approximately $20 \%$. EDTA did not affect Est56 activity, which indicated that Est56 activity is independent of divalent cations.

The nonionic detergents Triton X-100, Tween 20, and Tween 80 at $0.1 \%(v / v)$ significantly enhanced Est56 activity to $156.8 \%, 154.3 \%$, and $112.7 \%$, respectively. Est56 activity was inhibited or inactivated in the presence of $1 \%$ and $5 \%(v / v)$ of the other tested detergents (Table S6). The addition of the inhibitors DTT, PMSF, and DEPC at 1 and $10 \mathrm{mM}$ had detrimental effects on Est56 activity (Table S7). The inhibition of enzyme activity by PMSF and DEPC indicated that serine and histidine residues, respectively, are part of the Est56 catalytic triad [71].

\subsection{Sequence Analysis of Halotolerant Lipolytic Enzymes}

A phylogenetic tree was constructed to group 40 halotolerant lipolytic enzymes (Table S1) into families based on Arpigny and Jaeger [21] classification. As shown in Figure 3, these enzymes covered nine Arpigny and Jaeger families including family I, II, IV, V, VI, VII, VIII, XV, and XVII, as well as four new families including Est9x [27], EstLiu [24], lp_3505 [72], and EM3L4 [25]. Most of the analyzed halotolerant enzymes (18 enzymes) including Est56 belonged to Family IV. Family IV can be further divided into two sub-families based on the conserved GXSXG motif [34]. Est56 and other 10 halotolerant lipolytic enzymes belong to the GDSAG motif subfamily and the remaining 7 enzymes grouped into the GTSAG motif subfamily (Figure S5).

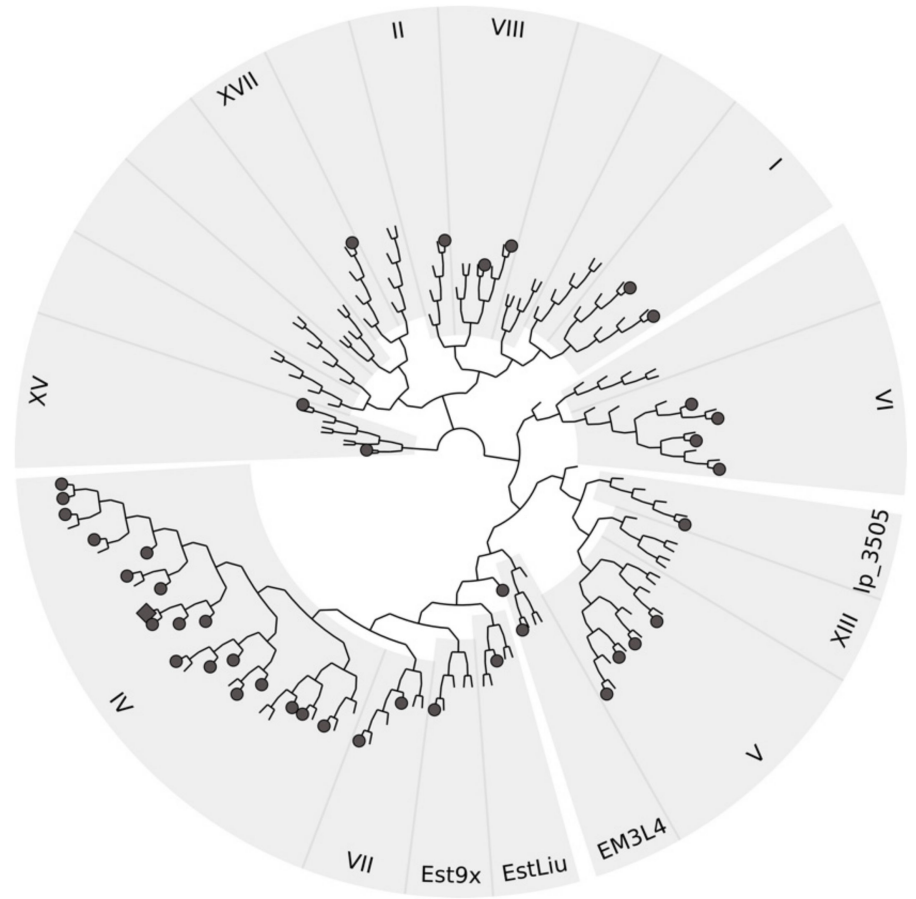

Figure 3. Phylogenetic classification of Est56 (closed diamond) and reported halotolerant (closed circle) lipolytic enzymes by neighbor-joining method. With the exception of Est56, other sequences were retrieved from GenBank.

Generally, the overall amino acid compositions among 3 different groups of selected and characterized halotolerant or halophilic enzymes were analyzed. The halotolerant lipolytic enzymes (HT_Lip; Table S1), the halophilic lipolytic enzymes (HP_Lip; Table S2), 
and other characterized halophilic enzymes (HP_Enz; Table S3) are pairwise different (ANOSIM test, $p<0.01$ in all three cases). The R values between HT_Lip and HP_Lip (0.4254) and HT_Lip and HP_Enz (0.4251) were higher than that of HP_Lip and HP_Enz (0.2065). This result indicated a high separation of amino acid composition between halotolerant (HT_Lip) and halophilic (HP_Lip and HP_Enz) enzymes, rather than within halophilic enzymes. This result was also consistent with the average dissimilarity revealed by SIMPER analysis (Table S8). The KW test identified that 12 residues (Asp, Glu, Lys, Arg, His, Leu, Met, Ile, Ala, Ser, Asn, and Gln) (Figure 4a) and theoretical pI values (Figure $4 \mathrm{~b}$ ) were significantly different $(p<0.05)$ among the three groups. The groups of halophilic enzymes HP_Lip and HP_Enz obtained significantly higher content of aspartic acid, glutamic acid, and arginine residues and lower content of lysine, leucine, methionine, isoleucine, and asparagine residues and theoretical $\mathrm{pI}$ values than those in halotolerant lipolytic enzymes HT_Lip (MW post hoc pairwise test, $p<0.05$ ). As reported above, the most notable feature for the halophilic adaptation of halophilic enzymes is the excessive number of acidic residues (Asp and Glu) compared to lysine residues. This is reflected by low theoretical pI values [15]. However, halotolerant lipolytic enzymes exhibited broad range of theoretical pI values (4.59 to 9.44) (Figure 4b). Among them, Est56 obtains high content of acidic residues (Asp and Glu, 12.12\%) and particularly low content of lysine residues $(0.7 \%)$, as well as a relatively low theoretical pI value of 4.97 .

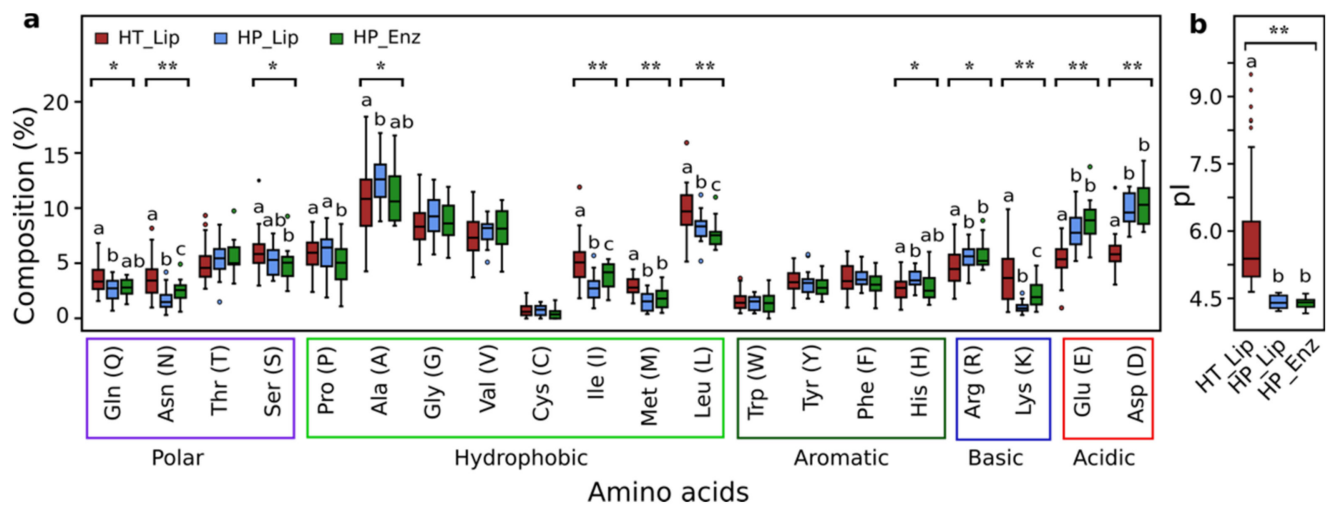

Figure 4. Comparison between halotolerant and halophilic enzymes. Box plots of (a) amino acid composition and (b) theoretical pI value of enzymes in groups HT_Lip (red), HP_Lip (blue), and HP_Enz (green). Statistical comparison was conducted by Kruskal-Wallis (KW) test $\left.{ }^{* *}, p<0.01 ;{ }^{*}, p<0.05\right)$ among three groups and Mann-Whitney (MW) post hoc test between pairwise groups (medians sharing a letter above boxes indicate no significant difference in the pairwise test).

\subsection{Structural Modeling of Est56}

The tertiary structure of Est56 is composed of a cap domain and an $\alpha / \beta$-hydrolase fold core domain. The cap domain of Est56 consists of $\alpha$-helices at the $\mathrm{N}$-terminal side ( $\alpha 1$ to $\alpha 2$ ) and between $\beta 6$ and $\beta 7$ ( $\alpha 6$ to $\alpha 7$ ) (Figure $5 a$ ). The core domain comprises six helices surrounded by eight $\beta$-strands that form parallel structures. The catalytic triad of Est56 consists of Ser ${ }^{132}$ located between $\beta 5$ and $\alpha 5$, Glu ${ }^{226}$ after $\beta 7$, and His $^{256}$ between $\beta 8$ and $\alpha 9$ (Figure 5a). The overall structure of Est56 superimposed well (TM-score 0.984; RMSD 0.48) on E40 [73], with a global amino acid sequence identity of 53\% (Figure 5b). The electrostatic potential of Est56 was calculated and described. The distribution of charges revealed that Est56 had negative charges on the surface (Figure 5c,d). 


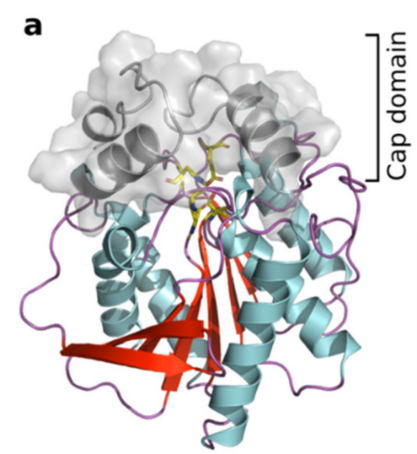

b

C

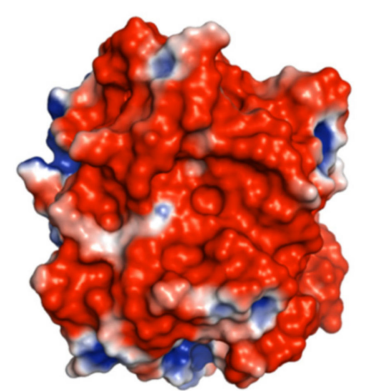

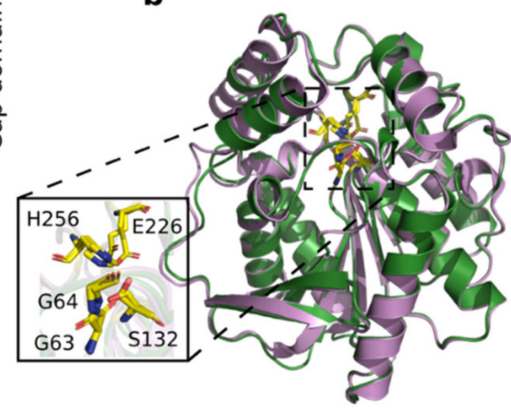

d

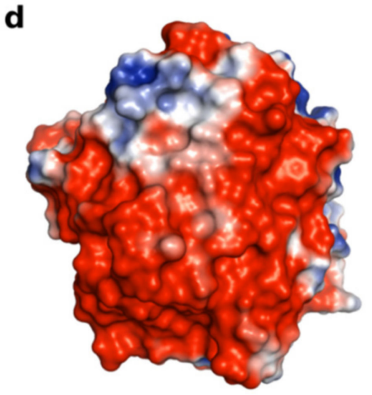

Figure 5. The modelled three-dimensional structure of Est56. (a) Ribbon representation of the Est56 monomer colored according to secondary structure elements. The overall structure is composed of two domains: cap domain and catalytic domain. (b) Superposition of Est56 (pink) onto its structural homolog E40 (PDB: 4xvc). The residues involved in stabilizing the oxyanion hole (Gly63 and Gly64) and catalytic triad (Ser94, Asp215 and His245) were indicated in stick representation (the sequence number is based on Est56 amino acid sequence). (c) Structural electrostatic potential of Est56. The most negative and most positive electrostatic potentials are indicated by red and blue, respectively, from -1 (red) to $+1 \mathrm{kT} / \mathrm{e}$ (blue). (d) The $180^{\circ}$ rotated view of (c).

\section{Discussion}

In this study, we identified a halotolerant esterase, Est56, from a compost metagenome and compared it to recently reported halotolerant enzymes (Table S1). In total, the 46 halotolerant lipolytic enzymes were grouped into 13 lipolytic families, which suggested a high diversity of halotolerant lipolytic enzymes (Figure 3). Including Est56, 29 halotolerant lipolytic enzymes were derived from metagenomes and correspondingly from uncultured microorganisms, which confirms the efficiency of metagenomic approaches in exploring novel enzymes $[74,75]$. The remaining 17 halotolerant enzymes were derived from individual microorganisms of which most thrive in saline environments, i.e., Zunongwangia profunda was derived from a surface seawater [24], Erythrobacter seohaensis from a tidal flat [76], Psychrobacter celer from a deep-sea sediment [77], and Alkalibacterium sp. SL3 from a soda lake sediment [78]. Some of the metagenome-derived halotolerant enzymes also originated from saline environments, such as marine water [27,37,41,79], deep sea sponges [42,80], deep-sea sediments [25,81], and deep-sea shrimps [82]. Recently, compost was reported as an habitat for halophilic and halotolerant microorganisms [83,84]. To our knowledge, Est56 is the first halotolerant esterase identified from a compost metagenome.

Est56 activity exhibited a $\mathrm{T}_{\text {opt }}$ at $50{ }^{\circ} \mathrm{C}$ and high stability at $30{ }^{\circ} \mathrm{C}$ (Figure 2 ). This is also the case for the majority of halotolerant esterases, which show a temperature optimum of enzyme activity between 35 and $50{ }^{\circ} \mathrm{C}$ and high stability at low temperatures (below $30{ }^{\circ} \mathrm{C}$ in most cases) [34,85-87]. Nevertheless, psychrophilic and thermophilic halotolerant lipolytic enzymes were also detected. For example, 7N9 [42], lp_3505 [72], EstS [11], Est10 [88], and EstLiu [24] displayed a temperature optimum ranging from 0 to $30{ }^{\circ} \mathrm{C}$, whereas E69 [76], Est9x [27], BmEST [89], and LipJ2 [39] exhibit their optimal activity between 60 and $80^{\circ} \mathrm{C}$. With respect to $\mathrm{pH}$, most of the halotolerant enzymes including Est56 are moderate alkaliphilic, with the optimum $\mathrm{pH}$ between 7.5 and 9 (Table S1). 
Generally, halotolerant lipolytic enzymes could be classified into three groups, according to their $\mathrm{NaCl}$-dependent catalytic activity (Table S1). In the first group comprising Lpc53E1 [80], PE10 [86], Lip3 [90], MGS-RG1 [82], LipC12 [40], Est9x [27], and Est700 [91] $\mathrm{NaCl}$ stimulated esterase activity was recorded over the tested concentration range $(0-4 \mathrm{M}$ in most cases). The second group harbors enzymes for which esterase activity continuously decreases with increasing $\mathrm{NaCl}$ concentration. Members of this group are 7N9 [42], ABO_1251 [79], Esth [92], ABO_1197 [79], EstS [11], and EstLiu [24]. For the third group, $\mathrm{NaCl}$ serves as an activator at low or moderate concentrations and as inhibitor at higher concentrations. Est56 belonged to this group, as its activity increased in the presence of $\mathrm{NaCl}$ up to a concentration of $1.5 \mathrm{M}$ and decreased at higher concentrations (Figure 2). Moreover, almost 50\% of the described halotolerant esterases such as E69 [76], ThaEst2349 [85], E25 [34], lp_3505 [72], and Est10 [88] follow this pattern.

Evaluation of enzyme stability towards salts revealed that Est56 retained its full activity after $24 \mathrm{~h}$ of incubation with $\mathrm{NaCl}$ or $\mathrm{KCl}$ concentrations ranging from 0 to $4 \mathrm{M}$ at $10{ }^{\circ} \mathrm{C}$ (Figure $2 \mathrm{~b}$ ). Similarly, almost unaltered residual activity was also detected for esterases such as Lpc53E1 [80], EaEST [93], Esth [92], EstSL3 [78], LipC12 [40], Est12 [77], Est-OKK [94], and Est700 [91]. Nevertheless, esterases such as EstSP [30], EstS [11], EstLiu [24], and H8 [81] were inhibited by high salt concentrations. Noteworthy are the stabilities of EM3L4 [25], ThaEst2349 [85], Lip3 [90], and Est10 [88], which were enhanced by addition of $\mathrm{NaCl}$. Although potassium ions are preferable for some halophilic enzymes [15,95], $\mathrm{NaCl}$ and $\mathrm{KCl}$ exhibited similar effects on Est56 activity and stability. This was tested only for a few other enzymes and similar results were obtained [29].

To shed a light on the mechanism of how halotolerant lipolytic enzymes resist salts, we compared the amino acid compositions among the groups HT_Lip, HP_Lip, and HP_Enz (Figure 4). The amino acid composition between halophilic and halotolerant proteins are significantly different, although enzymes in all groups were salt resistant. Our results were generally consistent with previous comparisons between halophilic and nonhalophilic homologs [9,96-99]. The most crucial feature of halophilic enzymes (HP_Lip and HP_Enz) compared to halotolerant lipolytic enzymes (HT_Lip) is the higher content of acidic residues (Asp and Glu) accompanied by a lower content of lysine residues (Figure 4a). This feature was also reflected by the lower pI values of halophilic enzymes (Figure $4 \mathrm{~b}$ ). Another consistent feature for halophilic enzymes is the low hydrophobicity $[4,15]$, which was presented by a low content of aliphalic hydrophobic residues (Leu, Met and Ile) in this study (Figure 4a). Significant difference in aromatic (Phe, Try, and Trp), small (Gly and Vla), and borderline (Ser and Thr) hydrophobic residues was not detected between HT_Lip and HP_Lip (Figure 4a). On the contrary, different results were reported for certain residues therein by comparing halophilic and non-halophilic homologs [97,99-102]. Moreover, a significantly lower content of polar amino acids (Gln and Asn) was recorded for HP_Lip compared to HT_Lip enzymes (Figure 4a), which has not been observed in other comparative analyses. In general, high acidity and low hydrophobicity reflected by the amino acid composition of halophilic enzymes is a distinctive feature for their "halophilic adaptation," which simultaneously enables them to resist salinity. Nonetheless, we could not find clear patterns in amino acid composition among halotolerant lipolytic enzymes, except the broad range of theoretical pI values (Figure $4 \mathrm{~b}$ ).

Recently, Dassarma and Dassarma [2] proposed a correlation between the halophilic character and acidic nature of proteins by reviewing the proteomes of different halophilic and halotolerant bacteria. Further studies on halophilic protein structure also confirmed that excessive surface-exposed acidic residues are the basis for halophilic adaptation [5,103-106]. Thus, given the low pI values of halophilic enzymes, we assume that halotolerant lipolytic enzymes with relatively low $\mathrm{pI}$ values would follow a similar haloadaptation as halophilic enzymes. Est56 exhibits a low pI value (4.97), with predominantly acidic residues located at its surface (Figure 5c,d). This is an indication that Est56 applies a salt resistance strategy similar to that of halophilic enzymes. Moreover, the distinctive feature of enhanced Est56 stability against denaturants (high temperatures and 
urea) mediated by $\mathrm{NaCl}$ suggests that Est 56 possess a halophilic character caused by the high acidic amino acid content. Another family IV esterase, ThaEst2349 (theoretical pI value 4.94), was also reported as halotolerant due to the high ratio of surface-exposed acidic residues [85]. Acidic amino acids were reported to have a greater capacity than other amino acids in keeping proteins hydralated, which is important for the solubility of protein under salt stress $[95,107,108]$. Interestingly, several reports on the haloadaptation of enzymes with higher $\mathrm{pI}$ values than Est56 indicated that instead of acidic residues, basic residues at protein surfaces played a key role in their halotolerance $[91,109,110]$. By site-directed mutagenesis, Zhang et al. [81] identified two basic residues Arg ${ }^{195}$ and $\mathrm{Arg}^{236}$ located on the surface of H8 (theoretical pI value 9.09), which were essential in the salt tolerance. Additional mechanisms were reported to contribute to the haloadaptation of halotolerant enzymes. By introducing hydrophobic residues in the cap and catalytic domain, the halotolerance of E40 (a family IV esterase) was significantly improved [31]. However, this adaptation hardly applies to all of the family IV esterases, since the cap domain is the most variable region [111]. The cap domain was even not observed for the family IV enzyme MGS-M1, which was also reported to resist high salinity [37]. Thus, the underlying mechanism for the haloadaptation of different lipolytic enzymes remains unclear.

To some extent, the hydration characteristics of halotolerant/halophilic enzymes may extend their function to nonaqueous environments [15,43]. In this study, Est56 was stable towards the tested water-miscible organic solvents (Table 2), and moderately tolerant to some water-immiscible organic solvents (Table 3). Some halotolerant lipolytic enzymes, such as LipC12 [40], estHIJ [112], EstSP [30], Est12 [77], and H8 [81] were also reported to resist the presence of organic solvents but to different degrees. The stability towards organic solvents could broaden Est56 application in organic solvent-mediated catalytic processes, such as flavor production in food industry, synthesis of antibiotics and antiinflammatory compounds in pharmaceutical industry, and production of pesticides for agricultural applications [113-116].

Additionally, other properties, such as the effect of metal ions, inhibitors, and detergents on Est56 activity were also studied. Est56 activity was enhanced by $\mathrm{Ca}^{2+}$ and $\mathrm{Al}^{3+}$ at 1 and $10 \mathrm{mM}$. Several esterases and lipases are also reported to be activated by $\mathrm{Ca}^{2+}$ ions $[117,118]$. However, it is rare for esterases to show an increased activity in the presence of $\mathrm{Al}^{3+}$ ions. Est56 activity was enhanced at a low concentration $(0.1 \%, v / v)$ of nonionic detergents such as Triton X-100, Tween 20, and Tween 80, while suppressed at high concentrations $(1 \%$ and $5 \%, v / v)$. This similar concentration-dependent effect of detergents on esterases was also found in other studies $[40,88,119]$.

\section{Conclusions}

A functional screening of a compost metagenome yielded an esterase, showing activity and stability over a salinity range of 0-4 M. The recently reported halotolerant lipolytic enzymes (40 in total) were also summarized and used for phylogenetic analysis in this study. To explore the haloadaptation of halotolerant lipolytic enzymes, their amino acid compositions were statistically compared with halophilic counterparts. However, no clear pattern was found in the amino acid composition in the halotolerant lipolytic enzymes. For Est56, the excessive content of acidic residues over lysine residues, as well as the predominantly negatively charged surface indicated that it applies a haloadaptation similar to that of halophilic enzymes. In addition, Est56 exhibits a tolerance toward various organic solvents and enhanced activity in the presence of $\mathrm{Ca}^{2+}$ and $\mathrm{Al}^{3+}$ ions and a low concentration $(0.1 \%, v / v)$ of nonionic detergents. Thus, Est56 is a novel biocatalyst with application potential, particularly under high salinity and in nonaqueous environments.

Supplementary Materials: The following are available online at https://www.mdpi.com/2073-4 425/12/1/122/s1, Figure S1: Genetic organization of the insert harboring est56 and BLAST search results for the predicted open reading frames (ORFs); Figure S2: Multiple sequence alignment of Est56 and its homologs; Figure S3: SDS-PAGE analysis of the purification of recombinant Est56 (including His $_{6}$-tag); Figure S4: Substrate specificity of Est56 towards $p$-NP esters of different chain 
length; Figure S5: Unrooted phylogenetic tree of family IV esterases using neighbor-joining method; Table S1: Features of characterized halotolerant lipolytic enzymes; Table S2: Lipolytic enzymes derived from halophilic archaea adapting the "salt in" strategy; Table S3: Characterized halophilic enzymes from other studies; Table S4: Purification of recombinant Est56; Table S5: Effect of metal ions and ethylenediaminetetraacetic acid (EDTA) on Est56 activity; Table S6: Effect of detergents on Est56 activity; Table S7: Effect of inhibitors on Est56 activity; Table S8: Amino acid composition comparison between halotolerant and halophilic enzymes.

Author Contributions: R.D. developed the concept and supervised the work. M.L. performed microbiological and molecular experiments and analysis of the sequences. All authors interpreted the results, contributed to the writing of the final version of the manuscript, and approved submission. All authors have read and agreed to the published version of the manuscript.

Funding: We acknowledge the support of Mingji Lu by “Erasmus Mundus Action 2-Lotus I Project." We acknowledge support by the Open Access Publication Funds of the University of Göttingen.

Institutional Review Board Statement: Not applicable.

Informed Consent Statement: Not applicable.

Data Availability Statement: All datasets are publicly available stored in or derived from NCBI databases (https:/ / www.ncbi.nlm.nih.gov). The amino acid sequence of Est56 is available in the GenBank database under accession number KR149569.1. The compost metagenome sequences are available in the NCBI sequence read archive (SRA) under the accession number SRR13115019.

Acknowledgments: We thank Silja Brady and Mechthild Bömeke for providing technical assistance. We also thank Sarah Zachmann for assistance.

Conflicts of Interest: The authors declare that the research was conducted in the absence of any commercial or financial relationships that could be construed as a potential conflict of interest.

\section{References}

1. Yadav, A.N.; Saxena, A.K. Biodiversity and biotechnological applications of halophilic microbes for sustainable agriculture. J. Appl. Biol. Biotechnol. 2018, 6, 48-55. [CrossRef]

2. Dassarma, S.; Dassarma, P. Halophiles and their enzymes: Negativity put to good use. Curr. Opin. Microbiol. 2015, 25, 120-126. [CrossRef] [PubMed]

3. Salma, M.; Abdulla, M.K.; Samina, M. Osmoadaptation in halophilic bacteria and archaea. Res. J. Biotechnol. $2020,15,154-161$.

4. Siglioccolo, A.; Paiardini, A.; Piscitelli, M.; Pascarella, S. Structural adaptation of extreme halophilic proteins through decrease of conserved hydrophobic contact surface. BMC Struct. Biol. 2011, 11, 50. [CrossRef] [PubMed]

5. Ishibashi, M.; Hayashi, T.; Yoshida, C.; Tokunaga, M. Increase of salt dependence of halophilic nucleoside diphosphate kinase caused by a single amino acid substitution. Extremophiles 2013, 17, 585-591. [CrossRef] [PubMed]

6. Moshfegh, M.; Shahverdi, A.R.; Zarrini, G.; Faramarzi, M.A. Biochemical characterization of an extracellular polyextremophilic $\alpha$-amylase from the halophilic archaeon Halorubrum xinjiangense. Extremophiles 2013, 17, 677-687. [CrossRef] [PubMed]

7. Cycil, L.M.; DasSarma, S.; Pecher, W.; McDonald, R.; AbdulSalam, M.; Hasan, F. Metagenomic insights into the diversity of halophilic microorganisms indigenous to the Karak Salt Mine, Pakistan. Front. Microbiol. 2020, 11, 1567. [CrossRef]

8. Oren, A. Bioenergetic aspects of halophilism. Microbiol. Mol. Biol. Rev. 1999, 63, 334-348. [CrossRef]

9. Ventosa, A.; Nieto, J.J.; Oren, A. Biology of moderately halophilic aerobic bacteria. Microbiol. Mol. Biol. Rev. 1998, 62, 504-544. [CrossRef]

10. Corral, P.; Amoozegar, M.A.; Ventosa, A. Halophiles and their biomolecules: Recent advances and future applications in biomedicine. Mar. Drugs 2020, 18, 33. [CrossRef]

11. Jiang, H.; Zhang, S.; Gao, H.; Hu, N. Characterization of a cold-active esterase from Serratia sp. and improvement of thermostability by directed evolution. BMC Biotechnol. 2016, 16. [CrossRef] [PubMed]

12. Bai, W.; Xue, Y.; Zhou, C.; Ma, Y. Cloning, expression, and characterization of a novel alkali-tolerant xylanase from alkaliphilic Bacillus sp. SN5. Biotechnol. Lett. 2012, 34, 2093-2099. [CrossRef] [PubMed]

13. Kumar, S.; Paul, D.; Bhushan, B.; Wakchaure, G.C.; Meena, K.K.; Shouche, Y. Traversing the "Omic" landscape of microbial halotolerance for key molecular processes and new insights. Crit. Rev. Microbiol. 2020, 46, 631-653. [CrossRef] [PubMed]

14. Delgado-García, M.; Valdivia-Urdiales, B.; Aguilar-González, C.N.; Contreras-Esquivel, J.C.; Rodríguez-Herrera, R. Halophilic hydrolases as a new tool for the biotechnological industries. J. Sci. Food Agric. 2012, 92, 2575-2580. [CrossRef] [PubMed]

15. Munawar, N.; Engel, P.C. Halophilic enzymes: Characteristics, structural adaptation and potential applications for biocatalysis. Curr. Biotechnol. 2013, 2, 334-344. [CrossRef]

16. Ortega, G.; Laín, A.; Tadeo, X.; López-Méndez, B.; Castaño, D.; Millet, O. Halophilic enzyme activation induced by salts. Sci. Rep. 2011, 1, 6. [CrossRef] 
17. Edbeib, M.F.; Aksoy, H.M.; Kaya, Y.; Wahab, R.A.; Huyop, F. Haloadaptation: Insights from comparative modeling studies between halotolerant and non-halotolerant dehalogenases. J. Biomol. Struct. Dyn. 2020, 38, 3452-3461. [CrossRef]

18. Sinha, R.; Khare, S.K. Protective role of salt in catalysis and maintaining structure of halophilic proteins against denaturation. Front. Microbiol. 2014, 5, 165. [CrossRef]

19. Vogler, M.; Karan, R.; Renn, D.; Vancea, A.; Vielberg, M.-T.; Grötzinger, S.W.; DasSarma, P.; DasSarma, S.; Eppinger, J.; Groll, M.; et al. Crystal structure and active site engineering of a halophilic $\gamma$-carbonic anhydrase. Front. Microbiol. 2020, 11, 742. [CrossRef]

20. Bardavid, R.E.; Oren, A. The amino acid composition of proteins from anaerobic halophilic bacteria of the order Halanaerobiales. Extremophiles 2012, 16, 567-572. [CrossRef]

21. Arpigny, J.L.; Jaeger, K.-E. Bacterial lipolytic enzymes: Classification and properties. Biochem. J. 1999, 343, 177-183. [CrossRef] [PubMed]

22. Bornscheuer, U.T. Microbial carboxyl esterases: Classification, properties and application in biocatalysis. FEMS Microbiol. Rev. 2002, 26, 73-81. [CrossRef] [PubMed]

23. Kovacic, F.; Babic, N.; Krauss, U.; Jaeger, K. Classification of lipolytic enzymes from bacteria. In Aerobic Utilization of Hydrocarbons, Oils and Lipids. Handbook of Hydrocarbon and Lipid Microbiology; Rojo, F., Ed.; Springer: Cham, Switzerland, 2019; pp. 1-35, ISBN 9783319397825.

24. Rahman, M.A.; Culsum, U.; Tang, W.; Zhang, S.W.; Wu, G.; Liu, Z. Characterization of a novel cold active and salt tolerant esterase from Zunongwangia profunda. Enzyme Microb. Technol. 2016, 85, 1-11. [CrossRef] [PubMed]

25. Lee, J.H.; Jeon, J.H.; Kim, J.T.; Lee, H.S.; Kim, S.J.; Kang, S.G.; Choi, S.H. Novel lipolytic enzymes identified from metagenomic library of deep-sea sediment. Evid. Based Complement. Altern. Med. 2011, 2011. [CrossRef]

26. Hu, Y.; Fu, C.; Huang, Y.; Yin, Y.; Cheng, G.; Lei, F.; Lu, N.; Li, J.; Ashforth, E.J.; Zhang, L.; et al. Novel lipolytic genes from the microbial metagenomic library of the South China Sea marine sediment. FEMS Microbiol. Ecol. 2010, 72, 228-237. [CrossRef] [PubMed]

27. Fang, Z.; Li, J.; Wang, Q.; Fang, W.; Peng, H.; Zhang, X.; Xiao, Y. A novel esterase from a marine metagenomic library exhibiting salt tolerance ability. J. Microbiol. Biotechnol. 2014, 24, 771-780. [CrossRef] [PubMed]

28. Asyari, M.; Aditiawati, P.; Akhmaloka; Hertadi, R. Cloning and sequence analysis of lipase gene of halophilic bacteria isolated from mud crater of Bledug Kuwu, Central Java, Indonesia. Biosci. Biotechnol. Res. Asia 2015, 12, 1903-1912. [CrossRef]

29. Jeon, J.H.; Lee, H.S.; Kim, J.T.; Kim, S.J.; Choi, S.H.; Kang, S.G.; Lee, J.H. Identification of a new subfamily of salt-tolerant esterases from a metagenomic library of tidal flat sediment. Appl. Microbiol. Biotechnol. 2012, 93, 623-631. [CrossRef]

30. Jayanath, G.; Mohandas, S.P.; Kachiprath, B.; Solomon, S.; Sajeevan, T.P.; Singh, I.S.B.; Philip, R. A novel solvent tolerant esterase of GDSGG motif subfamily from solar saltern through metagenomic approach: Recombinant expression and characterization. Int. J. Biol. Macromol. 2018, 119, 393-401. [CrossRef]

31. Li, P.-Y.; Zhang, Y.; Xie, B.-B.; Zhang, Y.-Q.; Hao, J.; Wang, Y.; Wang, P.; Li, C.-Y.; Qin, Q.-L.; Zhang, X.-Y.; et al. Structural and mechanistic insights into the improvement of the halotolerance of a marine microbial esterase by increasing intra- and interdomain hydrophobic interactions. Appl. Environ. Microbiol. 2017, 83, e01286-17. [CrossRef]

32. Mandrich, L.; de Pascale, D. An overview on thermal adaptation of esterases and lipases belonging to the HSL family: New insight on the computational analysis. Curr. Chem. Biol. 2011, 5, 17-28. [CrossRef]

33. Mandrich, L.; Menchise, V.; Alterio, V.; De Simone, G.; Pedone, C.; Rossi, M.; Manco, G. Functional and structural features of the oxyanion hole in a thermophilic esterase from Alicyclobacillus acidocaldarius. Proteins Struct. Funct. Genet. 2008, 71, $1721-1731$. [CrossRef]

34. Li, P.Y.; Ji, P.; Li, C.Y.; Zhang, Y.; Wang, G.L.; Zhang, X.Y.; Xie, B.B.; Qin, Q.L.; Chen, X.L.; Zhou, B.C.; et al. Structural basis for dimerization and catalysis of a novel sterase from the GTSAG motif subfamily of the bacterial hormone-sensitive lipase family. J. Biol. Chem. 2014, 289, 19031-19041. [CrossRef] [PubMed]

35. Chahinian, H.; Ali, Y.B.; Abousalham, A.; Petry, S.; Mandrich, L.; Manco, G.; Canaan, S.; Sarda, L. Substrate specificity and kinetic properties of enzymes belonging to the hormone-sensitive lipase family: Comparison with non-lipolytic and lipolytic carboxylesterases. Biochim. Biophys. Acta 2005, 1738, 29-36. [CrossRef]

36. Rao, L.; Zhao, X.; Li, Y.; Xue, Y.; Ma, Y.; Lu, J.R. Solution behavior and activity of a halophilic esterase under high salt concentration. PLoS ONE 2009, 4, e6980. [CrossRef] [PubMed]

37. Alcaide, M.; Stogios, P.J.; Lafraya, Á.; Tchigvintsev, A.; Flick, R.; Bargiela, R.; Chernikova, T.N.; Reva, O.N.; Hai, T.; Leggewie, C.C.; et al. Pressure adaptation is linked to thermal adaptation in salt-saturated marine habitats. Environ. Microbiol. 2015, 17, 332-345. [CrossRef] [PubMed]

38. Ai, L.; Huang, Y.; Wang, C. Purification and characterization of halophilic lipase of Chromohalobacter sp. from ancient salt well. J. Basic Microbiol. 2018, 58, 647-657. [CrossRef] [PubMed]

39. Castilla, A.; Panizza, P.; Rodríguez, D.; Bonino, L.; Díaz, P.; Irazoqui, G.; Giordano, S.R. A novel thermophilic and halophilic esterase from Janibacter sp. R02, the first member of a new lipase family (Family XVII). Enzyme Microb. Technol. 2017, 98 , 86-95. [CrossRef] [PubMed]

40. Glogauer, A.; Martini, V.P.; Faoro, H.; Couto, G.H.; Müller-Santos, M.; Monteiro, R.A.; Mitchell, D.A.; de Souza, E.M.; Pedrosa, F.O.; Krieger, N. Identification and characterization of a new true lipase isolated through metagenomic approach. Microb. Cell Fact. 2011, 10, 54. [CrossRef] 
41. Mohamed, Y.M.; Ghazy, M.A.; Sayed, A.; Ouf, A.; El-Dorry, H.; Siam, R. Isolation and characterization of a heavy metal-resistant, thermophilic esterase from a Red Sea Brine Pool. Sci. Rep. 2013, 3, 3358. [CrossRef]

42. Borchert, E.; Selvin, J.; Kiran, S.G.; Jackson, S.A.; O'Gara, F.; Dobson, A.D.W. A novel cold active esterase from a deep sea sponge Stelletta normani metagenomic library. Front. Mar. Sci. 2017, 4, 1-13. [CrossRef]

43. Marhuenda-Egea, F.C.; Bonete, M.J. Extreme halophilic enzymes in organic solvents. Curr. Opin. Biotechnol. 2002, 13, 385-389. [CrossRef]

44. Pérez, D.; Martín, S.; Fernández-Lorente, G.; Filice, M.; Guisán, J.M.; Ventosa, A.; García, M.T.; Mellado, E. A novel halophilic lipase, LipBL, showing high efficiency in the production of eicosapentaenoic acid (EPA). PLoS ONE 2011, 6, e23325. [CrossRef]

45. Oren, A. Industrial and environmental applications of halophilic microorganisms. Environ. Technol. 2010, 31, 825-834. [CrossRef] [PubMed]

46. Ryckeboer, J.; Mergaert, J.; Vaes, K.; Klammer, S.; Clercq, D.; Coosemans, J.; Insam, H.; Swings, J. A survey of bacteria and fungi occurring during composting and self-heating processes. Ann. Microbiol. 2003, 53, 349-410.

47. Kang, C.H.; Oh, K.H.; Lee, M.H.; Oh, T.K.; Kim, B.H.; Yoon, J.H. A novel family VII esterase with industrial potential from compost metagenomic library. Microb. Cell Fact. 2011, 10, 41. [CrossRef]

48. Ilmberger, N.; Meske, D.; Juergensen, J.; Schulte, M.; Barthen, P.; Rabausch, U.; Angelov, A.; Mientus, M.; Liebl, W.; Schmitz, R.A.; et al. Metagenomic cellulases highly tolerant towards the presence of ionic liquids-Linking thermostability and halotolerance. Appl. Microbiol. Biotechnol. 2012, 95, 135-146. [CrossRef] [PubMed]

49. Dougherty, M.J.; D’haeseleer, P.; Hazen, T.C.; Simmons, B.A.; Adams, P.D.; Hadi, M.Z. Glycoside hydrolases from a targeted compost metagenome, activity-screening and functional characterization. BMC Biotechnol. 2012, 12, 38. [CrossRef]

50. Lu, M.; Dukunde, A.; Daniel, R. Biochemical profiles of two thermostable and organic solvent-tolerant esterases derived from a compost metagenome. Appl. Microbiol. Biotechnol. 2019, 103, 3421-3437. [CrossRef]

51. Ishikawa, J.; Hotta, K. FramePlot: A new implementation of the frame analysis for predicting protein-coding regions in bacterial DNA with a high G + C content. FEMS Microbiol. Lett. 1999, 174, 251-263. [CrossRef]

52. Bendtsen, J.D.; Nielsen, H.; Von Heijne, G.; Brunak, S. Improved prediction of signal peptides: SignalP 3.0. J. Mol. Biol. 2004, 340, 783-795. [CrossRef] [PubMed]

53. Ye, J.; McGinnis, S.; Madden, T.L. BLAST: Improvements for better sequence analysis. Nucleic Acids Res. 2006, 34, W6-W9. [CrossRef] [PubMed]

54. Zhang, Y. I-TASSER server for protein 3D structure prediction. BMC Bioinform. 2008, 9, 40. [CrossRef] [PubMed]

55. Robert, X.; Gouet, P. Deciphering key features in protein structures with the new ENDscript server. Nucleic Acids Res. 2014, 42, 320-324. [CrossRef] [PubMed]

56. Bradford, M.M. A rapid and sensitive method for the quantitation of microgram quantities of protein utilizing the principle of protein-dye binding. Anal. Biochem. 1976, 72, 248-254. [CrossRef]

57. Lineweaver, H.; Burk, D. The determination of enzyme dissociation constants. J. Am. Chem. Soc. 1934, 56, 658-666. [CrossRef]

58. Fitter, J.; Haber-Pohlmeier, S. Structural stability and unfolding properties of thermostable bacterial $\alpha$-amylases: A comparative study of homologous enzymes. Biochemistry 2004, 43, 9589-9599. [CrossRef]

59. Tamura, K.; Stecher, G.; Peterson, D.; Filipski, A.; Kumar, S. MEGA6: Molecular evolutionary genetics analysis version 6.0. Mol. Biol. Evol. 2013, 30, 2725-2729. [CrossRef]

60. Felsenstein, J. Confidence limits on phylogenies: An approach using the bootstrap. Evolution 1985, 39, 783-791. [CrossRef]

61. Asnicar, F.; Weingart, G.; Tickle, T.L.; Huttenhower, C.; Segata, N. Compact graphical representation of phylogenetic data and metadata with GraPhlAn. PeerJ 2015, 3, e1029. [CrossRef]

62. Loukas, A.; Kappas, I.; Abatzopoulos, T.J. HaloDom: A new database of halophiles across all life domains. J. Biol. Res. 2018, 25, 2. [CrossRef] [PubMed]

63. Gasteiger, E.; Hoogland, C.; Gattiker, A.; Duvaud, S.; Wilkins, M.R.; Appel, R.D.; Bairoch, A. Protein identification and analysis tools on the ExPASy server. In The Proteomics Protocols Handbook; Humana Press: Totowa, NJ, USA, 2005; pp. $571-607$.

64. Oksanen, J.; Blanchet, F.G.; Friendly, M.; Kindt, R.; Legendre, P.; Mcglinn, D.; Minchin, P.R.; O’hara, R.B.; Simpson, G.L.; Solymos, P.; et al. Vegan: Community Ecology Package. Available online: https://cran.r-project.org/web/packages/vegan/ vegan.pdf (accessed on 30 October 2018).

65. Baker, N.A.; Sept, D.; Joseph, S.; Holst, M.J.; McCammon, J.A. Electrostatics of nanosystems: Application to microtubules and the ribosome. Proc. Natl. Acad. Sci. USA 2001, 98, 10037-10041. [CrossRef]

66. Lee, S.W.; Won, K.; Lim, H.K.; Kim, J.C.; Choi, G.J.; Cho, K.Y. Screening for novel lipolytic enzymes from uncultured soil microorganisms. Appl. Microbiol. Biotechnol. 2004, 65, 720-726. [CrossRef]

67. Jin, P.; Pei, X.; Du, P.; Yin, X.; Xiong, X.; Wu, H.; Zhou, X.; Wang, Q. Overexpression and characterization of a new organic solvent-tolerant esterase derived from soil metagenomic DNA. Bioresour. Technol. 2012, 116, 234-240. [CrossRef] [PubMed]

68. Dukunde, A.; Schneider, D.; Lu, M.; Brady, S.; Daniel, R. A novel, versatile family IV carboxylesterase exhibits high stability and activity in a broad pH spectrum. Biotechnol. Lett. 2017, 39, 577-587. [CrossRef] [PubMed]

69. Li, J.; Zhang, K.; Han, W. Cloning and biochemical characterization of a novel lipolytic gene from activated sludge metagenome, and its gene product. Microb. Cell Fact. 2010, 9, 83. [CrossRef]

70. Lindgren, M.; Westlund, P.-O. On the stability of chymotrypsin inhibitor 2 in a $10 \mathrm{M}$ urea solution. The role of interaction energies for urea-induced protein denaturation. Phys. Chem. Chem. Phys. 2010, 12, 9358. [CrossRef] 
71. Peng, Q.; Zhang, X.; Shang, M.; Wang, X.; Wang, G.; Li, B.; Guan, G.; Li, Y.; Wang, Y. A novel esterase gene cloned from a metagenomic library from neritic sediments of the South China Sea. Microb. Cell Fact. 2011, 10, 95. [CrossRef]

72. Esteban-Torres, M.; Santamaría, L.; de las Rivas, B.; Muñoz, R. Characterisation of a cold-active and salt-tolerant esterase from Lactobacillus plantarum with potential application during cheese ripening. Int. Dairy J. 2014, 39, 312-315. [CrossRef]

73. Li, P.; Chen, X.; Ji, P.; Li, C.; Wang, P.; Zhang, Y.; Xie, B.; Qin, Q.; Su, H.; Zhou, B.; et al. Interdomain hydrophobic interactions modulate the thermostability of microbial esterases from the hormone-sensitive lipase family. J. Biol. Chem. 2015, 290, 11188-11198. [CrossRef]

74. Khan, M.; Sathya, T.A. Extremozymes from metagenome: Potential applications in food processing. Crit. Rev. Food Sci. Nutr. 2018, 58, 2017-2025. [CrossRef] [PubMed]

75. Simon, C.; Daniel, R. Metagenomic analyses: Past and future trends. Appl. Environ. Microbiol. 2011, 77, 1153-1161. [CrossRef] [PubMed]

76. Huo, Y.Y.; Rong, Z.; Jian, S.L.; Xu, C.D.; Li, J.; Xu, X.W. A novel halotolerant thermoalkaliphilic esterase from marine bacterium Erythrobacter seohaensis SW-135. Front. Microbiol. 2017, 8, 2315. [CrossRef]

77. Wu, G.; Zhang, S.; Zhang, H.; Zhang, S.; Liu, Z. A novel esterase from a psychrotrophic bacterium Psychrobacter celer 3 Pb1 showed cold-adaptation and salt-tolerance. J. Mol. Catal. B Enzym. 2013, 98, 119-126. [CrossRef]

78. Wang, G.; Wang, Q.; Lin, X.; Ng, T.B.; Yan, R.; Lin, J.; Ye, X. A novel cold-adapted and highly salt-tolerant esterase from Alkalibacterium sp. SL3 from the sediment of a soda lake. Sci. Rep. 2016, 6, 19494. [CrossRef] [PubMed]

79. Tchigvintsev, A.; Tran, H.; Popovic, A.; Kovacic, F.; Brown, G.; Flick, R.; Hajighasemi, M.; Egorova, O.; Somody, J.C.; Tchigvintsev, D.; et al. The environment shapes microbial enzymes: Five cold-active and salt-resistant carboxylesterases from marine metagenomes. Appl. Microbiol. Biotechnol. 2015, 99, 2165-2178. [CrossRef] [PubMed]

80. Selvin, J.; Kennedy, J.; Lejon, D.P.H.; Kiran, G.S.; Dobson, A.D.W. Isolation identification and biochemical characterization of a novel halo-tolerant lipase from the metagenome of the marine sponge Haliclona simulans. Microb. Cell Fact. 2012, 11, 72. [CrossRef]

81. Zhang, Y.; Hao, J.; Zhang, Y.Q.; Chen, X.L.; Xie, B.B.; Shi, M.; Zhou, B.C.; Zhang, Y.Z.; Li, P.Y. Identification and characterization of a novel salt-tolerant esterase from the deep-sea sediment of the South China Sea. Front. Microbiol. 2017, 8, 441. [CrossRef]

82. Alcaide, M.; Tchigvintsev, A.; Martínez-Martínez, M.; Popovic, A.; Reva, O.N.; Lafraya, Á.; Bargiela, R.; Nechitaylo, T.Y.; Matesanz, R.; Cambon-Bonavita, M.-A.; et al. Identification and characterization of carboxyl esterases of gill chamber-associated microbiota in the deep-sea shrimp Rimicaris exoculata by using functional metagenomics. Appl. Environ. Microbiol. 2015, 81, 2125-2136. [CrossRef]

83. Oliveira, L.C.G.; Ramos, P.L.; Marem, A.; Kondo, M.Y.; Rocha, R.C.S.; Bertolini, T.; Silveira, M.A.; da Cruz, J.B.; de Vasconcellos, S.P.; Juliano, L.; et al. Halotolerant bacteria in the São Paulo Zoo composting process and their hydrolases and bioproducts. Braz. J. Microbiol. 2015, 46, 347-354. [CrossRef]

84. Chandna, P.; Mayilraj, S.; Kuhad, R.C. Bacillus pseudoflexus sp. nov., a moderately halophilic bacterium isolated from compost. Ann. Microbiol. 2016, 66, 895-905. [CrossRef]

85. De Santi, C.; Leiros, H.K.S.; Di Scala, A.; de Pascale, D.; Altermark, B.; Willassen, N.P. Biochemical characterization and structural analysis of a new cold-active and salt-tolerant esterase from the marine bacterium Thalassospira sp. Extremophiles 2016, 20, 323-336. [CrossRef] [PubMed]

86. Jiang, X.; Huo, Y.; Cheng, H.; Zhang, X.; Zhu, X.; Wu, M. Cloning, expression and characterization of a halotolerant esterase from a marine bacterium Pelagibacterium halotolerans B2T. Extremophiles 2012, 16, 427-435. [CrossRef] [PubMed]

87. Leite, A.E.T.; Briganti, L.; de Araújo, E.A.; Pellegrini, V.D.; Camilo, C.M.; Polikarpov, I. Low-resolution molecular shape, biochemical characterization and emulsification properties of a halotolerant esterase from Bacillus licheniformis. Eur. Biophys. J. 2020, 49, 435-447. [CrossRef]

88. Wu, G.; Wu, G.; Zhan, T.; Shao, Z.; Liu, Z. Characterization of a cold-adapted and salt-tolerant esterase from a psychrotrophic bacterium Psychrobacter pacificensis. Extremophiles 2013, 17, 809-819. [CrossRef]

89. Adı̈üzel, A.O. Production and characterization of thermo-, halo- and solvent-stable esterase from Bacillus mojavensis TH309. Biocatal. Biotransform. 2020, 38, 210-226. [CrossRef]

90. De Santi, C.; Altermark, B.; Pierechod, M.M.; Ambrosino, L.; de Pascale, D.; Willassen, N.-P. Characterization of a cold-active and salt tolerant esterase identified by functional screening of Arctic metagenomic libraries. BMC Biochem. 2016, 17. [CrossRef] [PubMed]

91. Zhang, W.; Xu, H.; Wu, Y.; Zeng, J.; Guo, Z.; Wang, L.; Shen, C.; Qiao, D.; Cao, Y. A new cold-adapted, alkali-stable and highly salt-tolerant esterase from Bacillus licheniformis. Int. J. Biol. Macromol. 2018, 111, 1183-1193. [CrossRef]

92. Hang, Y.; Ran, S.; Wang, X.; Jiao, J.; Wang, S.; Liu, Z. Mutational analysis and stability characterization of a novel esterase of lipolytic enzyme family VI from Shewanella sp. Int. J. Biol. Macromol. 2016, 93, 655-664. [CrossRef]

93. Lee, C.W.; Kwon, S.; Park, S.H.; Kim, B.Y.; Yoo, W.; Ryu, B.H.; Kim, H.W.; Shin, S.C.; Kim, S.; Park, H.; et al. Crystal structure and functional characterization of an esterase (EaEST) from Exiguobacterium antarcticum. PLoS ONE 2017, 12, e0169540. [CrossRef]

94. Yang, X.; Wu, L.; Xu, Y.; Ke, C.; Hu, F.; Xiao, X.; Huang, J. Identification and characterization of a novel alkalistable and salt-tolerant esterase from the deep-sea hydrothermal vent of the East Pacific Rise. Microbiology 2018, 7, e00601. [CrossRef]

95. Dennis, P.P.; Shimmin, L.C. Evolutionary divergence and salinity-mediated selection in halophilic archaea. Microbiol. Mol. Biol. Rev. 1997, 61, 90-104. [CrossRef] [PubMed] 
96. Margesin, R.; Schinner, F. Potential of halotolerant and halophilic microorganisms for biotechnology. Extremophiles 2001, 5, 73-83. [CrossRef] [PubMed]

97. Lanyi, J.K. Salt-dependent properties of proteins from extremely halophilic bacteria. Bacteriol. Rev. 1974, 38, 272-290. [CrossRef]

98. Madern, D.; Ebel, C.; Zaccai, G. Halophilic adaptation of enzymes. Extremophiles 2000, 4, 91-98. [CrossRef]

99. Hutcheon, G.W.; Vasisht, N.; Bolhuis, A. Characterisation of a highly stable $\alpha$-amylase from the halophilic archaeon Haloarcula hispanica. Extremophiles 2005, 9, 487-495. [CrossRef] [PubMed]

100. Kastritis, P.L.; Papandreou, N.C.; Hamodrakas, S.J. Haloadaptation: Insights from comparative modeling studies of halophilic archaeal DHFRs. Int. J. Biol. Macromol. 2007, 41, 447-453. [CrossRef]

101. Madern, D.; Pfister, C.; Zaccai, G. Mutation at a single acidic amino acid enhances the halophilic behaviour of malate dehydrogenase from Haloarcula marismortui in physiological salts. Eur. J. Biochem. 1995, 230, 1088-1095. [CrossRef]

102. Paul, S.; Bag, S.K.; Das, S.; Harvill, E.T.; Dutta, C. Molecular signature of hypersaline adaptation: Insights from genome and proteome composition of halophilic prokaryotes. Genome Biol. 2008, 9, R70. [CrossRef]

103. Winter, J.A.; Christofi, P.; Morroll, S.; Bunting, K.A. The crystal structure of Haloferax volcanii proliferating cell nuclear antigen reveals unique surface charge characteristics due to halophilic adaptation. BMC Struct. Biol. 2009, 9, 1-15. [CrossRef]

104. Tadeo, X.; Ló Pez-Mé Ndez, B.; Trigueros, T.; Laín, A.; Castañ, D.; Millet, O. Structural basis for the amino acid composition of proteins from halophilic Archea. PLoS Biol. 2009, 7, e1000257. [CrossRef] [PubMed]

105. Munawar, N.; Engel, P.C. Overexpression in a non-native halophilic host and biotechnological potential of NAD+-dependent glutamate dehydrogenase from Halobacterium salinarum strain NRC-36014. Extremophiles 2012, 16, 463-476. [CrossRef] [PubMed]

106. Coquelle, N.; Talon, R.; Juers, D.H.; Girard, É.; Kahn, R.; Madern, D. Gradual adaptive changes of a protein facing high salt concentrations. J. Mol. Biol. 2010, 404, 493-505. [CrossRef] [PubMed]

107. Oren, A.; Gavrieli, I.; Gavrieli, J.; Kohen, M.; Lati, J.; Aharoni, M. Microbial communities in the Dead Sea-Past, present and future. In Adaptation to Life at High Salt Concentrations in Archaea, Bacteria, and Eukarya. Cellular Origin, Life in Extreme Habitats and Astrobiology; Gunde-Cimerman, N., Oren, A., Plemenitaš, A., Eds.; Springer: Berlin/Heidelberg, Germany, 2005; Volume 9, pp. 27-39, ISBN 1402036337.

108. Bieger, B.; Essen, L.-O.; Oesterhelt, D. Crystal structure of halophilic dodecin: A novel, dodecameric flavin binding protein from Halobacterium salinarum. Structure 2003, 11, 375-385. [CrossRef]

109. Altermark, B.; Helland, R.; Moe, E.; Willassen, N.P.; Smalås, A.O. Structural adaptation of endonuclease I from the cold-adapted and halophilic bacterium Vibrio salmonicida. Acta Crystallogr. Sect. D Biol. Crystallogr. 2008, 64, 368-376. [CrossRef] [PubMed]

110. Sivakumar, N.; Li, N.; Tang, J.W.; Patel, B.K.C.; Swaminathan, K. Crystal structure of AmyA lacks acidic surface and provide insights into protein stability at poly-extreme condition. FEBS Lett. 2006, 580, 2646-2652. [CrossRef]

111. Kim, T.D. Bacterial hormone-sensitive lipases (bHSLs): Emerging enzymes for biotechnological applications. J. Microbiol. Biotechnol. 2017, 27, 1907-1915. [CrossRef] [PubMed]

112. Noby, N.; Hussein, A.; Saeed, H.; Embaby, A.M. Recombinant cold-adapted halotolerant, organic solvent-stable esterase (estHIJ) from Bacillus halodurans. Anal. Biochem. 2020, 591, 113554. [CrossRef]

113. Panda, T.; Gowrishankar, B.S. Production and applications of esterases. Appl. Microbiol. Biotechnol. 2005, 67, 160-169. [CrossRef]

114. Hasan, F.; Shah, A.A.; Hameed, A. Industrial applications of microbial lipases. Enzyme Microb. Technol. 2006, 39, $235-251$. [CrossRef]

115. Karan, R.; Capes, M.D.; DasSarma, S. Function and biotechnology of extremophilic enzymes in low water activity. Aquat. Biosyst. 2012, 8, 4. [CrossRef] [PubMed]

116. Lopez-Lopez, O.; Cerdan, M.; Siso, M. New extremophilic lipases and esterases from metagenomics. Curr. Protein Pept. Sci. 2014, 15, 445-455. [CrossRef] [PubMed]

117. Rathi, P.; Bradoo, S.; Saxena, R.K.; Gupta, R. A hyper-thermostable, alkaline lipase from Pseudomonas sp. with the property of thermal activation. Biotechnol. Lett. 2000, 22, 495-498. [CrossRef]

118. Castro-Ochoa, L.D.; Rodríguez-Gómez, C.; Valerio-Alfaro, G.; Oliart Ros, R. Screening, purification and characterization of the thermoalkalophilic lipase produced by Bacillus thermoleovorans CCR11. Enzyme Microb. Technol. 2005, 37, 648-654. [CrossRef]

119. Kamarudin, N.H.A.; Rahman, R.N.Z.R.A.; Ali, M.S.M.; Leow, T.C.; Basri, M.; Salleh, A.B. A new cold-adapted, organic solvent stable lipase from mesophilic Staphylococcus epidermidis AT2. Protein J. 2014, 33, 296-307. [CrossRef] [PubMed] 